\title{
How Does Strategic Choice Affect Business Results? A Case Study of Mutual Guarantee Societies
}

\author{
Pedro Núñez-Cacho Utrilla (Correspondence author) \\ Facultad de CC Sociales y Jurídicas, Campus de las Lagunillas s/n \\ Jaén University, 23071 Jaen, Spain
}

Tel: 34-953-213-485Ｅ-mail: pnunez@ujaen.es

Félix A. Grande Torraleja

Facultad de CC Sociales y Jurídicas, Campus de las Lagunillas s/n Jaén University, 23071 Jaen, Spain

Tel: 34-953-213-010Ｅ-mail: fagrande@ujaen.es

Agustín Muñoz Vázquez

Facultad de CC Sociales y Jurídicas, Campus de las Lagunillas s/n

$$
\begin{gathered}
\text { Jaén University } \\
23071 \text { Jaen, Spain }
\end{gathered}
$$

Tel: 34-953-212-208Ｅ-mail: avazquez@ujaen.es

\section{Manuel Aranda Ogáyar}

Facultad de CC Sociales y Jurídicas, Campus de las Lagunillas s/n

$$
\begin{gathered}
\text { Jaén University } \\
23071 \text { Jaen, Spain }
\end{gathered}
$$

Tel: 34-953-211-865Ｅ-mail: mogayar@ujaen.es

Received: January 5, 2012

doi:10.5539/ijbm.v7n7p51
Accepted: February 2, 2012

Published: April 1, 2012

\begin{abstract}
We analyzed the relationship between various strategies and the results for certain strategic variables for Mutual Guarantee Societies (MGSs). After performing a factor analysis, three types of strategies were identified. Subsequently, cluster analysis allowed us to group the MGSs into four clusters. The information obtained from this analysis suggests that MGS results are conditioned by their strategies.
\end{abstract}

Keywords: Mutual Guarantee Societies, SME'S, Strategy

\section{Introduction}

A problem facing businesses today is lack of funding. The global economic situation, particularly the situation in the Spanish economy, has forced financial institutions to reconsider requirements for companies seeking external financing. In this scenario, MGSs are particularly important because their purpose is to facilitate financial access for small and medium-sized enterprises (SMEs).

Numerous studies explain a company's profitability according to the implemented strategic option. However, few studies address this issue with regard to MGSs, whose main purpose is to facilitate financial access for SMEs on more favorable terms (Díez et al., 2011; Fuente and Priede, 2003; and Fuente Cabrero, 2007, Pérez, 2010). This study examines whether a relationship exists between profitability and the strategy a MGS 
implements. In short, we focus on clarifying why some companies (in our case MGSs) achieve better (or different) results than others.

One possible answer to this question is to consider the strategy to be a determinant of the results, as evidenced by the literature (Cavusgil and Zou, 1994; Cool and Schendel, 1987, 1988; Cooper, 1984; Galbraith and Schendel, 1983; Hambrick and Schecter, 1983; Linsu and Yooncheol, 1988; Parker and Helms, 1992) and more recently, Hyvönen, 2007; Jenning et al., 2003; Luo and Ho Park, 2001; O'Regan and Ghobadian, 2004; Parmell, et al., 2006. However, not all of these studies reveal a directly proportional relationship between the two variables, which makes this study more compelling. Therefore, determining whether using certain strategies leads to better results for MGSs is our main objective.

Regarding the theoretical framework, we note that, notwithstanding the explanations provided in the appropriate section, we opted for the Bowman's Strategy Clock because it is an excellent adaptation of the Porter's Generic Strategies Model. Its usefulness lies in its flexibility in interpreting combined strategies and in its relaxation of some of the Porter's assumptions that have proven inadequate in the business world. In our analysis of mutual guarantee companies, we found a financial business type sector with its own characteristics such as mutuality and involvement of the public sector and their own strategy,

Therefore, after this introduction, we analyze both the framework in which to circumscribe MGS as well as the theoretical framework. Then, we define the assumptions, choose the methodology, and analyze the results. Finally, a summary and conclusions are provided.

\section{Theoretical framework and hypotheses}

MGSs began in Spain in the late 1970s with the aim of facilitating credit access for SMEs. The purpose of these societies is to provide guarantees for members to third parties in order to achieve advantageous financing to support business project development. Capital is comprised of two types of partners: protectors and participants. Protectors are mere shareholders, and partners are SMEs that can receive guarantees and services from an MGS.

In the late 1990s after a difficult start, which included state mergers and interventions, MGSs significantly increased their business volume. Financial systems and business environments provided higher confidence levels in MGSs. As a result, MGSs grew significantly, and they became more committed to being effective facilitation instruments, which could access financing for SMEs. Ultimately, they became a major contributor to regional development (Contreras, et al., 1999).

The refinancing system supported this growth, which allowed the development of MGSs due to their lower management costs. The MGSs and provided balanced profitability, and although their aim was not to maximize profit, operational practice did not lead to systematically incurred operating losses. As noted by Núñez-Cacho et al. (1996), another factor that gave MGSs greater stability was the provision of other financial services, especially in consulting, training, and planning of their work. These services resulted in alternative income streams and gave the societies the means to strengthen member loyalty. In addition, special agreements reached among MGSs, protector institutions, and financial institutions allowed members to obtain guarantees at very competitive prices.

Schematically and after analyzing the system as a whole, we made the following observations: the outstanding risk assumed by the system increased significantly each year, the profitability accounts of MGSs improved significantly, and the societies gradually broke even. For these reasons, they continued to grow and strengthen in the Spanish financial system (Pérez, 2002). Solvency ratios improved significantly because of the technical provisions fund's strength and the lower capital requirements that resulted from the refinancing of operations. A single society operating regionally accounted for $32.2 \%$ of the system's total exposure, while the ten smallest contributed less than $11 \%$ exposure. This high concentration has been observed since the early $1990 \mathrm{~s}$ and is linked to the societies' management, the institutional support provided to them, the management teams' ability to generate new business, and the more aggressive and less-conservative position towards risk taking by larger societies. We cannot forget that the purpose of MGSs is to increase participating members' employment and investment, providing a guarantee that they alone cannot offer. Furthermore, the concentration of outstanding risk does not proportionally correspond to MGSs' resources. Financial guarantees comprise the largest business volume of MGSs, and the operations they finance are mainly unsecured (approx. 38\%); in some cases, they require personal guarantees and in others, mortgage guarantees.

When defining the theoretical principles on which this work is based, we used a strategy model called Strategy Clock or Bowman's Strategy Clock because we believe that it is currently the most appropriate theoretical tool for explaining the different competitive strategies companies have at their disposal, as indicated by Guerras and 
Navas (2007) and Safón and Escribá (2002) nationally and by Johnson and Scholes (1999) in an international context.

The Strategy Clock stemmed from criticism of the Porter's Model from a dual perspective, theory, and practice. Faulkner and Bowman $(1992,1995)$ revealed how the cost leadership strategy was not fully available for all companies, thereby questioning Porter's Model. Subsequently, other authors (Parnell, 2006; Parnell and Hershey, 2005) extended the criticism and suggested other approaches. Additionally, Safón and Escribá (2002) carried out an appropriate criticism that was summarized by four motives. First, the definitions of the terms "cost leadership," "stuck in the middle," "differentiation," and "focus" were ambiguous and confusing. Second, the risk of using "only" one of the three generic strategies when sharing these would more appropriately minimize risks. Third, the presumption that being stuck in the middle was always negative when the market considers this option a possibility for choosing a competitive strategy. And, fourth, the model was static and deterministic and did not consider the environment's influence on strategic choice. From these approaches, Bowman (1992), with contributions from Kotler (1992) and subsequent adaptations by Strategor (1995) and Johnson and Scholes (1999), configured an alternative Porter's model called the Strategy Clock.

Choosing a theoretical framework is neither an easy decision nor free from debate on what is and what is not a competitive strategy. Therefore, we abandoned Porter's restrictive approaches and accepted an updated, realistic model of competitive strategy in a company. We sought to answer whether a company could successfully pursue several competitive generic strategies, *which the Strategy Clock allowed us to do. We also wanted to know if being "stuck in the middle" according to Porter's typology was true. Although it is not very innovative, contrasting this hypothesis is the first obligation of every researcher who opts to break away from Porter and who wishes to determine if the alternative model is valid.

For Porter, there was no alternative between using cost leadership and differentiation, either in the entire market or in a part of it (focus), which identified the intermediate position as detrimental and led to negative results. In contrast, Bowman and Johnson (1992) opted for the Strategy Clock typology, where the low-cost strategy (cost leadership) is position 1-2 on the clock, differentiation is position 4, and a hybrid strategy is position 3 . The hybrid strategy may be appropriate in certain scenarios and environments and lead to different results.

In reviewed reference studies that regarded the relationship between results and strategies, this possibility was studied, and the results were inconclusive. It may be necessary to analyze why there is not unanimity case by case, but this is not this work's aim. Our aim is to add results to studies that have analyzed this problem and to test hypotheses that validate one alternative or another. On the side closest to Porter's work, we find Campbell-Hunt (2000), Dess and Davis (1984), Galbraith and Schendel (1983), Parker and Helms (1992), and White (1986), among others. These studies conclude, overall, that the halfway position leads to negative results. In contrast, some authors, such as Kotha and Orne (1989), Miles and Show (1978), Miles (1992), Miller (2011), Thiétart (1988), and Wright and Parsinia (1988), point out that combining the competitive strategies of differentiation and cost can lead to positive results. Miller and Friesen (1986) indicate that it is preferable to choose either cost or differentiation, although some companies in certain contexts can combine these successfully.

At this point, we formulated the following hypotheses:

H1: MGSs that follow a hybrid strategy outperform other MGSs.

H2: A focus on sectors and products has an effect on profitability variables.

H3: The MGSs are concentrated in a few strategic groups and do not occupy all of the Strategy Clock positions.

\section{Methodology}

\subsection{Measures used}

To test the above hypothesis, we used data from the 22 MGSs in Spain from 1997 to 2009. By analyzing these data, we defined a set of variables considered to be representative of the different strategy types to which we referred above (e.g., to analyze the strategy, we will use the competitive variables associated with the generic strategies of the Strategy Clock shown in Table 1).

\section{Insert Table 1 here}

Most of the variables used in this work have already been used and therefore validated in a number of previous studies that had similar objectives to ours. However, due to the particular characteristics of the finance sector, we have adapted several of them. Out of the fifteen variables we initially considered, we selected ten that best represented the strategic behaviors of MGSs. The next section defines and justifies the variables used. The 
number of additional services (NSER) variable identifies how many services and guarantee operations MGSs offer. New product development results in diversification that increases market share and attracts new customers. Fuentes (2002) used this variable to measure diversity in financial product offerings.

The number of branches (OFIC) variable measures the number of offices open in different locations. Its measurement is important because we believe that the more offices, the greater the number of members and therefore a greater ability to offer additional services. This argument is consistent with that of Fernández and Suárez (1998), as the branch network is the most direct way to reach customers and achieve greater market penetration. This variable is also used in other studies such as that of González (2000), which applied to the financial sector. The number of provinces in which the company operates (PROV) variable shows behavior similar to the previous variable, provides an idea of size, and reflects the different degrees of MGS development (Gómez 1994). It has been used in studies on efficiency in the banking sector (Maudos, 2001).

The relative importance of new services (IRNV) variable measures the weight of the revenue that different services produce compared with income from guarantees in a society's total income. With this variable, we seek to determine to what extent companies offer complementary services versus its main activity. This variable was constructed using data provided by each society and considering the sector's particularities.

From MGS data, we studied the segmentation degree of each society, both in the sectors in which it primarily operates as well as the guarantee's final sector provided by the MGS. Specifically, we have calculated the Herfindahl Index'which is generally accepted as an indicator of concentration (Jiménez and Betancor, 2011). The beneficiary sectors of the guarantee are reflected in the industry concentration variable (HSEC), and from the destination sectors of the guarantees, we obtain the concentration variable by type of operation (HPRO).

First, with regard to efficiency variables, we state that efficiency can be defined as an expression that measures the ability or quality of performance of an economic entity to achieve compliance with certain objectives (output) from initial resources (input). This capacity is compared with that obtained by other companies in the sector. The measure of efficiency allows the assessment of company behavior and increases understanding about the structure of an economic sector (Sánchez, 2008). Thus, we define the operating efficiency (EFEX) variable as the ratio of operating costs of societies to their total assets. In short, this is an indicator reflecting the optimization of resource use in a society. Pérez, Quesada, and Fernández de Guevara (2000) have used this ratio in banking sector studies.

Similarly, productive efficiency (EFPR) is a ratio adapted to these businesses' specific characteristics, arising from classic economic and financial analysis productivity ratios. EFPR gives us an idea of outstanding risk units formalized over the year for each monetary unit invested in personnel. Mas and Gómez (1993) have used this indicator to identify strategic groups in savings banks. They have also used the ratio of income over total assets (INAC), which relates the company's income to total fixed assets and provides the measure of assets needed to generate income. The guarantee price (PVAL) variable is defined as the income ratio, relating provision of guarantees funds and risk for the year. It indicates the price the member paid for every euro guaranteed and price levels among different societies. This variable has been used in studies such as that by Gómez (1994), and it is referred to as guarantee commissions.

A distinguishing feature of MGSs compared with other companies lies in the concept of profitability because by definition MGSs are not-for-profit businesses. Thus, the societies' results were defined by three variables drawn from information they provided: the volume of outstanding risk (RIVI), the number of formalized guarantee operations (NAVA), and the number of participating members (NSOC). These are indicators of more developed societies (Fuente 2007) and of orderly growth levels in societies, which have not caused detriment to their assets and have remained at recommended levels for solvency and default coverage (Pérez, 1999). Several researchers have concluded that these variables yield good results (Gómez, 1994; Sesto, 1994).

\subsection{Methods}

To achieve the goals set out by this study, we first performed a factor analysis to reduce the strategic variables considered and identify, if possible, new variables with the strategic dimensions considered in our study. Later, using this first approach based on factor analysis, we grouped companies in different clusters, according to the factors obtained, to identify companies with similar strategies and to confirm if significant differences existed among different performance measures considered, as determined with a contrast ANOVA. Among the studies using this methodology, the following should be noted: Dess and Davis (1984), Galbraith and Schender (1983), Hambrick and Schecter (1983) and Miller (1992). 


\section{Analysis of results}

Prior to conducting a factor analysis, we determined the data suitability for applying this technique. To do so, we calculated the correlation matrix among all variables considered, as well as a series of indicators that show the association degree between variables [determinant of the correlation matrix, Bartlett's test of sphericity, and the Kaiser-Meyer-Olkin index (KMO)]. The variables needed to be highly intercorrelated to make sense of the factor analysis, and we found that the correlation matrix must have a value greater than 0.5 . The correlation matrix determinant has a value of 0.000 , which was small enough to conclude that variables with very high intercorrelations exist.

The Bartlett sphericity test, used to confirm the hypothesis that the correlation matrix is an identity matrix (meaning that the intercorrelations among the variables are zero, which shows that it would not make sense to continue with the factor analysis), allowed us to reject the null hypothesis and allowed us to conclude that the variables were intercorrelated (Table 2). This finding, in addition to the KMO index value (0.55), indicates that the data used in our study were suitable for factor analysis.

\section{Insert Table 2 here}

In developing the factor analysis, we chose the principal components analysis approach to extract the factors, selecting those whose eigenvalue exceeds unity. To facilitate the interpretation of the factors, we used the Varimax rotation method. Specifically, only three factors met this requirement, explaining $71.5 \%$ of the variance. The interpretation of extracted factors was conducted by studying the composition of the factor loadings in the rotated component matrix (Table 3) and by using the strategies from the Strategy Clock. In this case, the variables we associated with each factor were as follows:

Factor 1: Number of offices (OFIC), Productive efficiency (EFPR), Efficiency of operations (EFEX), and Income from assets (INAC). By virtue of these variables' nature and from the perspective of the strategic classification used, we considered them to be part of a differentiation strategy.

Factor 2: Relative importance of new services in the revenue of the society (IRNV), Number of provinces in which the society has permanent locations (PROV), the Guarantee price (PVAL), and Number of additional services (NSER). From the analysis of these variables, we believe that they represent a hybrid strategy.

Factor 3: Herfindahl Index of concentration by sectors (HSEC) and the Herfindahl Index of concentration in products (HPRO). Given the nature of the variables, this factor can be interpreted as a segmentation strategy.

\section{Insert Table 3 here}

Our goal was to determine the MGS categories or groups, which demonstrated significant intragroup homogeneity and extra-group heterogeneity. To achieve this goal, we used the factor scores obtained through factor analysis as described in the previous section. Table 4 presents the solution in which we have identified four strategic groups. For the identification, we first performed a hierarchical clustering analysis, and from the analysis of the data obtained (record clustering and dendrogram coefficients, etc.), we concluded that there were four clusters. Subsequently, to confirm this result, we used the non-hierarchical k-means procedure. From the data obtained, we decided to use four clusters, of which the Euclidean distance was the measure used to determine the proximity between each case and its corresponding group's center. In turn, the ANOVA analysis showed that the four factors analyzed were significantly different from the four clusters considered.

\section{Insert Table 4 here}

After identifying the four clusters and determining the number of cases in each $(9,7,4$, and 1 respectively, including the loss of 1 case during the clustering process), the next step was to find an explanation for this distribution of cases in the clusters, which allowed us to identify each one of them. Thus, from the strategic typology proposed for this work and the strategic variables' mean scores in the factor analysis, we obtained the following conclusions:

Cluster 1: Included the MGSs that were positioned in a strategy with an unfavorable position, according to its position on the Strategy Clock. This cluster presented the highest value, although negative, which was very different from the other variables; it is precisely the negative sign that determined its position on the Strategy Clock.

Cluster 2: Included the MGSs that were positioned in a hybrid strategy because the cluster corresponded with the column's highest value. We note that the positive sign indicates that this strategy is destined for success.

Cluster 3: Included MGSs that were clearly positioned in a segmentation strategy. 
Cluster 4: This cluster included MGSs that were positioned in a differentiation strategy, and it consisted of only one case, which led us to believe that the cluster analysis identified an "outlier" (an atypical case) whose behavior required explanation. Specifically, we confirmed that this MGS accounted for much of the risk of the entire MGS sector (33\%, and 10 of the remaining 21 only accounted for $10 \%$ ), and it was by far was the MGS with the highest level of social capital and number of formalized guarantees.

After establishing the strategic groups, we then defined the relationship between the business strategy and MGS results as measured by the variables mentioned above.

\subsection{Relationship between the strategy and results}

To contrast the different hypotheses, we conducted an ANOVA to identify the significant differences between the clusters considered in relation to the variables of "performance" used in our study. From this analysis, presented in Table 5, we observed significant differences in the three outcome variables considered within clusters 1 and 2.

\section{Insert Table 5 here}

The above table assists in testing the hypotheses proposed in this paper.

First, we compared the hypothesis that relates to the position in a hybrid strategy with MGS results. From the data in Table 5, we observed that the hybrid strategy's position had a positive impact on all the variables representing the MGS (i.e., a strategy of this type has a positive effect on attracting partners, signing guarantees, and the MGS outstanding risk). Second, the hypothesis that the concentration of industries and products as measured by the Herfindahl index of concentration has an effect on the outcome variables cannot be proven because as observed, no significant differences exist. Third, the hypothesis that most of the positions on the Strategy Clock are empty was confirmed, given that in the factor analysis, only three of the eight positions on the Strategy Clock were identified.

\section{Discussion and conclusions}

When we analyzed mutual guarantee companies, we found a financial sector with its own characteristics such as mutuality and involvement of the public sector. The analysis we developed allowed us to identify a strategy indicator of success, which highlighted the influence of the guarantee's low price and its incorporation of other services (e.g., training, financial advisory, and consulting). These strategies in turn provided additional revenue to the society and allowed for a scope of operations that encompassed several provinces. We also identified a group of companies that were affected by the factor that defines a hybrid strategy, but with a negative sign, which showed their disadvantageous position compared with that of the previous group. In addition, we can conclude that poorer results result from a high guarantee price, the minimal incorporation of new services, low alternative revenues from the guarantees, and an operational structure that includes few provinces. The strategic position of these companies on the Strategy Clock also suggests that they could use strategies employed by monopolistic companies.

As mentioned, one of the clusters corresponded to a society that accounts for $33 \%$ of the risk of the sector and appeared to be positioned within a differentiation strategy due to the importance of its branch network and its efficient use of resources and revenues over assets. We could not reach definitive conclusions because it is an outlier. We identified a group of companies with a segmentation position, and we did not reach any conclusions about results, which showed that although the Herfindahl indices indicate that these societies are highly concentrated in one sector or in one type of service, this fact does not yield better results.

If new variables are added in future research, more conclusive results regarding strategic approaches can be obtained. At the theoretical level, it is feasible to combine resource and capability-based theories as well as generic competitive strategies that are applicable in the financial sector. It would be interesting to use resource and capability-based theories to explain why some societies grow unevenly compared with others.

\section{References}

Bowman, C. (1992). Charting Competitive strategy. D. Faulkner and G. Johnson (eds.), The Challenge of Strategic Management. Londres, Kogan Page, pp. 64-83.

Bowman, C., \& Johnson, G. (1992). Surfacing Competitive Strategies. European Management Journal, Vol. 10, 2, pp. 210-220. http://dx.doi.org/10.1016/0263-2373(92)90071-B

Campbell-HunT, C. (2000). What have we learned about generic competitive strategy? A metaanalysis. Strategic $\begin{array}{lccc}\text { Management } & \text { Journal, } & 21, & \text { pp. } \\ \text { http://dx.doi.org/10.1002/(SICI)1097-0266(200002)21:2<127::AID-SMJ75>3.0.CO;2- }\end{array}$ 
Cavusgil, S. T., \& Zou, S. (1994). Marketing strategy-performance relationship: An investigation. Journal of Marketing, vol. 58, pp. 1-21. http://dx.doi.org/10.2307/1252247

Contreras, I., Jiménez Z, J., Trujillo, A., Jiménez, F., Palacín, M.J., García, R., \& Pérez, C. (1999). Resultados de la valoración del sistema de sociedades de garantía recíproca and capital riesgo andaluz. Boletín económico de Andalucia, No 26, pp. 129-144.

Cool, K., \& Schendel, D. (1987). Strategic Group Formation and Performance: the Case of the U.S. Pharmaceutical Industry, 1963-1982. Management Science, 33, 9, pp. 1102-1124. http://dx.doi.org/10.1287/mnsc.33.9.1102

Cool, K., \& Schendel, D. (1988). Performance Differences among Strategic Groups Members. Strategy Management Journal, Vol. 9, pp. 207-223. http://dx.doi.org/10.1002/smj.4250090302

Cooper, R. (1984). The Stategy-Performance Link in Product Innovation. R\&D Management, Vol. 14, 4, pp. 247-260. http://dx.doi.org/10.1111/j.1467-9310.1984.tb00521.x

Dess, G. G., \& Davis, P.S. (1984). Porter's generic strategies as determinants of strategic group memberships and organizational performance. Academy of Management Journal, 27, 3, pp. 467-488. http://dx.doi.org/10.2307/256040

Díez Z, F., Blanco, A., \& Prado, C. (2010). Medición de la legitimidad organizativa: el caso de las Sociedades de Garantía Recíproca. Cuadernos de Economía and Dirección de la Empresa, núm. 43, junio, pp. 115-143.

Faulkner, D., \& Bowman, C. (1992). Generic Strategies and Congruent Organisational Structures: Some Suggestions. European Management Journal, Vol. 10, 4, pp. 494-500. http://dx.doi.org/10.1016/0263-2373(92)90016-W

Faulkner, D., \& Bowman, C. (1995). The essence of Competitive Strategy. Hertfordshide, Prentice Hall.

Fernández, Z., \& Suárez, I. (1998). Las cajas de ahorro: estrategia and estructura. Papeles de Economía Española, $\mathrm{n}^{\circ} 74-75$, pp. 202-221.

Fuente Cabrero, C. (2007). Claves del éxito de las Sociedades de Garantías Recíproca en el periodo 1994-2000. Madrid, Delta Publicaciones.

Fuente Cabrero, C., \& Priede, T. (2003). El reafianzamiento de las Sociedades de Garantía Recíproca Españolas. Evolución histórica and configuración actual. Madrid. CESGAR: Madrid.

Fuentes, I. (2002). Diversificación del negocio bancario en España: estrategias and cambios en su estructura. Papeles de Economía Española, n 94, pp. 146-161.

Galbraith, C., \& Schendel, D. (1983). An empirical analysis of strategy types. Strategic Management Journal, 4, 2, pp. 153-176. http://dx.doi.org/10.1002/smj.4250040206

Gómez, E. (1994). El sistema de SGR en Andalucía. Granada, Universidad Granada.

Gonzalez, Z.E. (2000). El reto de la calidad del servicio financiero. Investigaciones Europeas de Dirección and Economía de Empresa, Vol. 6, pp.71-92.

Guerras, L. A., \& Navas, J. E. (2007). La Dirección Estratégica de la Empresa. Madrid, Thomson Civitas.

Hambrich, D. C., \& Schecter, S, M. (1983). Turnaround Strategies for Mature Industrial-product Business Units. Academy of Management Journal, 26, pp. 231-248. http://dx.doi.org/10.2307/255972

Hyvönen, J. (2007). Strategy, performance measurement techniques and information technology of the firm and their links to organizational performance. Management Accounting Research, Vol. 18, 3, pp. 343-359. http://dx.doi.org/10.1016/j.mar.2007.02.001

Jenning, D. F., Rajaratnan, D., \& Lawrence, F.B. (2003). Strategy-performance relationships in service firms: A test for equifinality. Journal of Managerial Issues, Vol. 15, 2, pp. 208-220.

Jiménez, J.L., \& Betancor, O. (2011). Comportamiento estratégico de las aerolíneas ante la entrada del tren de alta velocidad: aplicación al mercado español. Vía Libre, Junio 2011, 4-25.

Johnson, J., \& Scholes, K. (1999). Exploring Corporate Strategy, (5ª ed.). Englewood Cliffs, Prentice Hall.

Khota, S., \& Orne, D. (1989). Generic manofacturing strategies: A conceptual synthesis. Strategic Management Journal, 10, 3, pp. 211-231. http://dx.doi.org/10.1002/smj.4250100303

Kotler, P. (1992). Dirección de Marketing, (7ª ed.). Prentice hall, Madrid, pp. 550-558. 
Linsu, K., \& Yooncheol, L. (1988). Enviroment, Generic Strategies, and Performance in a Rapid. Academy of Management Journal, Vol. 31, 4, pp. 802-828. http://dx.doi.org/10.2307/256339

Luo, J., \& Ho Park, S. (2001). Strategic alignment and performance of market-seeking MNCs in China. Strategy $\begin{array}{llllll}\text { Management Journal, } & \text { Vol. } & 22, & 2, & \text { pp. } & 141-155 .\end{array}$ http://dx.doi.org/10.1002/1097-0266(200101)22:2<141::AID-SMJ151>3.0.CO;2-O

Mas, F.J., \& Gómez, J.C. (1993). Análisis de la competencia de cajas de ahorro: grupos estratégicos. Esic Market, Vol. 16, 2. pp. 143-155.

Maudos, J. (2001). Rentabilidad, estructura de mercado and eficiencia en la banca. Revista de Economía Aplicada, $\mathrm{n}^{\circ} 25$, pp. 193-207.

Miles, R. E., \& Snow, C. C. (1987). Organizational Strategy, structure and processes. New York: Mc Graw-Hill.

Miles, R. E. (2010). Lessons Learned, Ignored, Forgotten and Reborn: Organizations and Management 1960 to Today. Journal of Management Inquiry, 20: 4-7. http://dx.doi.org/10.1177/1056492610375916

Miller, D. (1992). Generic strategies, classification, combinations and context. Advances in strategic management, 8, pp. 391-408.

Miller, D., \& Friesen, P. H. (1986). Porter's (1980) generic strategies and performance: An empirical examination with American data, Part I: testing Porter. Organization studies, 7, 1, pp. 37-55. http://dx.doi.org/10.1177/017084068600700103

Montijano Guardia, F. (2001). Comportamiento estratégico de las entidades aseguradoras. Actualidad Financiera, vol. 21, pp:121-151.

Núnez-Cacho, P., Grande, F, \& Muñoz, A. (1996). Presente and futuro de las sociedades de garantía recíproca, Actas del $5^{\circ}$ Congreso de Economía Regional de Castilla and León. Libro, 1, pp. 138-149.

O`regan, N., \& Ghobadian, A. (2004). Re-visiting the strategy-performance question: an empirical analysis. International Journal of Management \& Decision Making, Vol. 5, 2,3, pp. 144-170.

Parker, B., \& Helms, M.M. (1992). Generic strategies and firm performance in declining industry. Management International Review, 32, 1, pp. 23-39.

Parmel, J. A., O`regen, N., \& Ghobadian, A. (2006). Measuring performance in competitive strategy research. International Journal of Management \& Decision Making, Vol. 7, 4, pp. 408-417.

Parnell, J. A. (2006). Generic Strategies after two decades: a reconceptualization of competitive strategy. Management Decision, Vol. 44, 8, pp. 1139-1151. http://dx.doi.org/10.1108/00251740610690667

Parnell, J. A., \& Hershey, L. (2005). The strategy-performance relationship revisited: The blessing and curse of the combination strategy. International Journal of Commerce \& Management, Vol. 15, 1, pp. 17-33.

Pérez López, C. (2000). Las Sociedades de Garantía Recíproca en España. 1994-1999. Madrid, Civitas.

Pérez López, C. (1999). Las sociedades de garantía recíproca: Estructura del balance 1994-1998. Actualidad Financiera, 04, pp. 19-28.

Pérez López, C. (2002). Las sociedades de garantía recíproca: su evolución reciente. Harvard Deusto Finanzas and Contabilidad, n 50, pp. 70-80.

Pérez, F., Quesada, J., \& Fernández de Guevara, J. (2000). Especialización and costes en los sistemas bancarios europeos (1992-1998). Papeles de Economía Española, no 84-85, pp. 136-152.

Pérez, C. (2010). Las Sociedades de Garantía Recíproca en España. Actividad avalista desarrollada. Revista del Centro de Investigación. Universidad La Salle, Vol. 9, Núm. 33, enero-junio, pp. 61-74.

Safón, V., \& Escribá, A. (2002). Estrategias competitivas: implicaciones teóricas, prácticas and docentes. Revista Europea de Dirección and Economía de la Empresa, vol. 11, 2, pp. 119-140.

Sánchez, L. C. (2008). Eficiencia de las sociedades de garantía recíproca españolas tras su reforma (1999-2001), Contribuciones a la Economía revista académica virtual 1 Número Internacional Normalizado de Publicaciones Seriadas ISSN 1696-8360.

Sesto Pedreira, M. A. (1994). Evolución and desarrollo de las Sociedades de Garantía Recíproca. Perspectivas del Sistema Financiero, 35-80.

Strategor Détrie, J. P. (1995). Estrategia, estructura, decisión, identidad. Política General de la Empresa. 
Barcelona, Masson S.A.

Thiétart, R. A. (1988). Success strategies for business that perform poorly. Interfaces, 18, 3, pp. 32-45.

White, R. E. (1986). Generic business strategies, organizational context and performance: an empirical investigation. Strategic Management Journal, 7, 3, pp. 217-231. http://dx.doi.org/10.1002/smj.4250070304

Wright, P., \& Parsinia, A. (1988). Porter's synthesis of generic business strategies: A critique. Industrial Management, (May-June), pp. 20-23.

Table 1. Strategic Variables

\begin{tabular}{|l|l|l|}
\hline Nomenclature & Variable & $\begin{array}{l}\text { Indicative } \\
\text { strategy }\end{array}$ \\
\hline OFIC & Number of offices & Differentiation \\
Eifferentiation \\
EFEX & Production efficiency & Differentiation \\
INAC & Operating Efficiency & Differentiation \\
IRNS & Income from assets & Hybrid \\
PROV & Relative importance of new services & Hybrid \\
PVAL & Number of provinces of operations. & Hybrid \\
NSER & Guarantee price & Hybrid \\
HPRO & Number of additional services offered & Segmentation \\
HSEC & Concentration of operations receiving guarantees & Segmentation \\
\hline
\end{tabular}

Own elaboration.

Table 2. Adequacy measures

\begin{tabular}{|l|l|l|}
\hline \multicolumn{2}{|l|}{ Kaiser-Meyer-Olkin measure of sample adequacy. } & 0.550 \\
\hline Bartlett test of sphericity & Approximate Chi-square & 138.505 \\
\cline { 2 - 3 } & Gl & 45 \\
\cline { 2 - 3 } & Sig. & 0.000 \\
\hline
\end{tabular}

Table 3. Rotated Component Matrix

\begin{tabular}{|c|c|c|c|}
\hline \multirow{2}{*}{} & \multicolumn{3}{|c|}{ Component } \\
\cline { 2 - 4 } & 1 & 2 & 3 \\
\hline OFIC & 0.849 & 0.350 & 0.194 \\
\hline EFPR & 0.734 & 0.093 & -0.388 \\
\hline EFEX & 0.927 & -0.143 & -0.017 \\
\hline INAC & 0.921 & -0.199 & -0.085 \\
\hline IRNV & -0.171 & 0.727 & 0.039 \\
\hline PROV & 0.417 & 0.541 & 0.424 \\
\hline PVAL & 0.011 & -0.828 & 0.231 \\
\hline NSER & 0.332 & 0.567 & 0.553 \\
\hline HPRO & -0.098 & -0.056 & 0.683 \\
\hline HSEC & -0.092 & -0.006 & 0.790 \\
\hline
\end{tabular}

Extraction Method: Principal Component Analysis. (Varimax) 
Table 4. Final Cluster Centers

\begin{tabular}{|l|l|l|l|l|}
\hline & \multicolumn{5}{|l|}{ Clusters } & 3 & 4 \\
\cline { 2 - 5 } & 1 & 2 & -0.50078 & $\mathbf{3 . 8 8 7 6 3}$ \\
\hline Differentiation Strategy & -0.40160 & 0.24712 & 0.84345 & -0.93234 \\
\hline Hybrid Strategy & $\mathbf{- 0 . 9 2 1 1 0}$ & $\mathbf{0 . 8 3 5 4 9}$ & $\mathbf{- 1 . 3 1 9 1 7}$ & -0.58903 \\
\hline Segmentation strategy & 0.18843 & 0.59569 & \\
\hline
\end{tabular}

Table 5. Means of the Variables in the Clusters that were Considered

\begin{tabular}{|l|l|l|l|l|}
\hline Variable & p value & Cluster 1 & Cluster 2 & Cluster 3 \\
\hline NSOC & $0.015^{*}$ & $2148.89\left(2^{*}\right)$ & $6643.57\left(1^{*}\right)$ & 2399.25 \\
\hline NAVA & $0.012^{*}$ & $6693\left(2^{*}\right)$ & $40819.71\left(1^{*}\right)$ & 7008.50 \\
\hline RIVI & $0.014 *$ & $66549334\left(2^{*}\right)$ & $3.0 \mathrm{E}+008\left(1^{*}\right)$ & $1.0 \mathrm{E}+008$ \\
\hline $\begin{array}{l}\text { * Denotes the existence of significant differences } \\
\text { Figures in parentheses indicate the group for which the mean differences are significant using the Scheffe } \\
\text { test }\end{array}$
\end{tabular}

